\title{
Post-fledging dispersal and habitat use of a reintroduced population of the Crested Ibis (Nipponia nippon)
}

\author{
Zhiping Huo ${ }^{1}$, Junfeng Guo ${ }^{1}$ Xia $\mathrm{Li}^{2}$ and Xiaoping $\mathrm{Yu}^{1 *}$
}

\begin{abstract}
Background: Knowledge of dispersal movement of birds and their habitat preference during the post-fledging period is fundamental to the understanding of their ecological and evolutionary processes. The Crested Ibis is now being reintroduced to protected sites within its historical range, with the goal of establishing a self-sustaining population that may eventually qualify the species for delisting.
\end{abstract}

Methods: We carried out an ecological study of post-fledging dispersal and habitat use of a reintroduced population of the Crested Ibis (Nipponia nippon) from 2008 to 2012 in Ningshan County, China, by using banding and radio-telemetry methods.

Results: In about two weeks (an average of 14.3 days) after fledging, the activities of the fledglings were concentrated in a range of about $100 \mathrm{~m}$ around their natal sites, such as the oak-pine forest patches at the edge of open habitats. During this period, fledglings were still partially dependent upon parental care and fed typically on a daily basis. Siblings increasingly became independent by mid-August and then gradually moved away from their natal sites to post-fledging dispersal locations. During the period of the post-fledging dispersal process, most juveniles moving southwest were concentrated at the mean direction $\left(\mu=254.6^{\circ}, \breve{s}=70.5^{\circ}\right)$ with a mean dispersal distance of $5.1 \mathrm{~km}$. It took an average of 56.4 days to disperse from the natal territory to the first wintering area. Also, forging habitats for juvenile ibis varied with time and local conditions. For example, paddy fields were used most frequently among all habitat types, while shallow rivers just from August to October. Masson pine (Pinus massoniana) was often regarded as the roosting tree species preferred by the Crested Ibis, with the highest utilization rate among all the roosting habitat types. The juveniles of the wild population dispersed four times as far as that of the reintroduced population, but the overall pattern of post-fledging dispersal is similar for the reintroduced and wild populations.

Conclusions: Our results are very useful for us to predict the distance and direction of dispersal under various landscape conditions in other released sites. The project is a good example for reintroducing endangered species to their former ranges, and will be valuable for the protection of reintroduced populations of this critically and other endangered species.

Keywords: Crested Ibis, Ningshan County, Post-fledging dispersal, Habitat use, Reintroduced population

\footnotetext{
*Correspondence: yuxp64@163.com

'College of Life Sciences, Shaanxi Normal University, Xi'an 710062, China

Full list of author information is available at the end of the article
} 


\section{Background}

Dispersal is one of the most important life-history traits for animals. The study of dispersal has received increasing attention from animal ecologists during the past two decades (Clobert et al. 2001, Barbraud et al. 2003). Knowledge of dispersal movements is fundamental to our understanding of many ecological and evolutionary processes, as well as for the design of successful conservation strategies (Paradis et al. 1998). It is often defined as the permanent movement an animal makes from its natal site to the place where it reproduces or would have reproduced if it had survived and found a mate (Howard 1960). Greenwood and Harvey (1982) suggested distinguishing between "natal dispersal" and "breeding dispersal", the latter referring to the movements undertaken by adults between breeding sites. Post-fledging dispersal refers to the movements of the young after they become independent of their parents and leave their natal territory to move to wintering areas (Bull et al. 1988). In the avian life-cycle this stage is poorly understood, but limited studies have documented post-fledging periods lasting up to two months (Morton 1991; Baker 1993). For migratory birds, some investigators have assumed that once the young disappear from their natal site they begin a slow movement to the south (Bent 1953; Pulich 1976). The young of resident species have been shown to stay in the general vicinity of where they were hatched, but will move into different habitats (Nolan 1978; Rappole and Ballard 1987; Bocetti 1993).

The Crested Ibis (Nipponia nippon) was once one of East Asia's most widespread and well-known birds, but deforestation and destruction of habitat has led to successive extinctions of Russian, Korean and Japanese populations in the 20th century (Yamshina 1967; Archibald et al. 1980; Yusuda 1988). The Chinese population was presumed extinct for two decades preceding the 1981 discovery of seven birds in Yangxian County, Shaanxi Province (Liu 1981). During the past 30 years, a great deal of conservation effort, both in-situ and ex-situ, has been undertaken by researchers and the local government. The wild population in China has increased to approximately 800 and more than 700 captive-bred individuals now reside in eight protection centers located in China, Japan and Korea. This rare species is now being reintroduced to protected sites within its historical range, with the goal of establishing stable, secure populations that may eventually qualify the species for delisting (Yu et al. 2009).

The first reintroduction was at Zhaigou village, Ningshan County in China's Shaanxi Province. From May 2007 to October 2011, 56 captive-bred individuals (29 males and 27 females) were released into the wild ( $\mathrm{Li}$ et al. 2013). From these birds, 14 breeding pairs have, so far, produced 46 fledglings. With a $62.5 \%$ survival rate for released birds, this first reintroduction program in China has had a promising start (Li et al. 2011). Post-fledging dispersal is the original stage for juveniles, laying the foundations for the entire dispersal process, which to a certain extent, also determines the following series of the dispersal process. Therefore, the study of post-fledging dispersal can contribute to the study of the entire dispersal process, necessary to mark out successfully the strategies to protect the reintroduced populations. Also, the study of habitat utilization of the Crested Ibis helps us to understand the use of spatial resources and the effect of their variety on the movements of the birds. Post-fledging dispersal patterns and habitat utilization during the breeding period by the Crested Ibis in the wild have been studied recently (Yu et al. 2010; Liu et al. 2003), but dispersal behavior and habitat relationships in the reintroduced population remain unclear. Therefore, we designed the current study in order to explore the population dynamics and the habitat utilization of a reintroduced population of the Crested Ibis, attempting to provide theoretical and practical bases for reintroduction and conservation.

The Crested Ibis establishes a small breeding territory of no more than $50 \mathrm{~m}$ in diameter (Shi and Cao 2001). The species is not highly territorial. To establish a new population, it is essential for released birds not only to survive successfully during the establishment phase of pairing and breeding, but also to disperse successfully into wintering areas. The onset of juvenile dispersal is usually more or less arbitrarily defined on the basis of some estimation of the typical size of the territory of adults (Ferrer 1993; Walls and Kenward 1995). Juvenile dispersal is characterized by an initial wandering and exploratory phase that contrasts with the restricted predispersal movements. Such contrast is likely to be identifiable as a period of increased variability in the distance to the nest and hence could be used to identify the onset of juvenile dispersal. Thus, Soutullo et al. (2006) used a criterion of distance to determine the onset of dispersal. We monitored movements of the Crested Ibis following release using banding and radio-telemetry. Specifically, we sought 1) to document distance and direction of post-fledging dispersal, 2) to determine changes in habitat use between natal and dispersal sites, 3) to compare dispersal patterns between released and wild population in Yangxian County studied by Yu et al. (2010) and 4) to propose management suggestions for conservation and future release.

\section{Methods}

\section{Study area}

From 2008 to 2012, we conducted fieldwork in Ningshan County $\left(33^{\circ} 07^{\prime}-33^{\circ} 50^{\prime} \mathrm{N}, 108^{\circ} 02^{\prime}-108^{\circ} 56^{\prime} \mathrm{E}\right)$, located on the south slope of the Qinling mountains in central China's Shaanxi Province. The study area lies in a warm, 
temperate zone and is moderately humid. The annual temperature averages $12.5^{\circ} \mathrm{C}$, with a minimum in January $\left(-12.8^{\circ} \mathrm{C}\right)$ and a maximum in July $\left(36^{\circ} \mathrm{C}\right)$. The frostfree period is 215 days. The annual precipitation is $899 \mathrm{~mm}$ with July through September being the wettest time of the year (Ningshan County meteorological station).

The elevation of the study area ranges from 700 to $1100 \mathrm{~m}$. This area is often developed for rice paddies interspersed with dry farmlands in the valley and for forest stands on hillsides. The study area includes all areas used by both young and adult birds for dispersal. A large number of shallow rivers and streams roll southward through this area into the Hanjiang River, one of the longest tributaries of the Yangtze River. Almost all nesting areas were in pine and oak forests characterized by trees with diameter at breast height (DBH) ranging from 5 to $40 \mathrm{~cm}$ and canopy height between 10 and $25 \mathrm{~m}$, planted on slopes near local farmer settlements. These patches are primarily deciduous, broadleaf forests where the dominant tree species include Quercus variabilis, Pinus tabulaeformis, P. massoniana, and Platycladus orientalis. Forest patches provide $80 \%$ of the coverage used by ibis for nesting.

In the study area, the Crested Ibis forages in paddy fields, shallow rivers, arid wastelands, grasslands and streams. The birds roost in P. massoniana and other tree species. During the daytime, in between foraging grounds, the ibis temporarily rests on rock outcrops, poles and at the edges of fields.

\section{Study birds}

We followed 25 individuals (Table 1, two juveniles from two broods in 2008, five juveniles from three broods in 2009 , five juveniles from four broods in 2010, seven juveniles from six broods in 2011 and six juveniles from four broods in 2012) of the reintroduced population, fledged between 2008-2012 from the time of fledging throughout the post-fledging dispersal period. During

Table 1 Nest site characteristics and fledging details for $\mathbf{2 5}$ marked Crested Ibis juveniles at Zhaigou village, Ningshan County in Shaanxi Province

\begin{tabular}{|c|c|c|c|c|c|c|c|}
\hline Nest & Year & $\begin{array}{l}\text { Parent } \\
\text { (male/female) }\end{array}$ & Nest substrate & Bands of fledglings & $\begin{array}{l}\text { Hatching rate } \\
\text { (hatched/clutch) }\end{array}$ & $\begin{array}{l}\text { Fledging rate } \\
\text { (fledged/clutch ) }\end{array}$ & Date fledged \\
\hline 1 & 2008 & $082 / 375$ & Pinus massoniana & W07 & $3 / 3$ & $2 / 3$ & 23 May \\
\hline \multirow[t]{2}{*}{2} & \multirow[t]{2}{*}{2008} & \multirow[t]{2}{*}{ 359/R27 } & \multirow[t]{2}{*}{ Populus davidiana } & W08 & \multirow[t]{2}{*}{$1 / 1$} & \multirow[t]{2}{*}{$1 / 1$} & 19 July \\
\hline & & & & B710 & & & 8 June \\
\hline \multirow[t]{2}{*}{3} & \multirow[t]{2}{*}{2009} & \multirow[t]{2}{*}{ 359/R27 } & \multirow[t]{2}{*}{ Pinus massoniana } & B711 & \multirow[t]{2}{*}{$4 / 4$} & \multirow[t]{2}{*}{$3 / 4$} & 9 June \\
\hline & & & & B712 & & & 11 June \\
\hline 4 & 2009 & R21/R20 & Pinus massoniana & B721 & $2 / 2$ & $2 / 2$ & 15 June \\
\hline 5 & 2009 & 221/309 & Pinus massoniana & B723 & $1 / 1$ & $1 / 1$ & 11 June \\
\hline 6 & 2010 & 359/R27 & Pinus massoniana & B725 & $4 / 4$ & $3 / 4$ & 14 June \\
\hline 7 & 2010 & W07/W19 & Pinus massoniana & B728 & $3 / 3$ & $2 / 3$ & 29 June \\
\hline \multirow{2}{*}{8} & \multirow{2}{*}{2010} & \multirow{2}{*}{ R30/W01 } & \multirow{2}{*}{ Pinus massoniana } & B730 & \multirow{2}{*}{$2 / 2$} & \multirow{2}{*}{$2 / 2$} & 2 July \\
\hline & & & & B731 & & & 3 July \\
\hline 9 & 2010 & $221 / 309$ & Pinus massoniana & B737 & $2 / 2$ & $1 / 2$ & 27 June \\
\hline 10 & 2011 & W07/W19 & Pinus massoniana & B740 & $4 / 4$ & $3 / 4$ & 28 May \\
\hline \multirow[b]{2}{*}{11} & \multirow[b]{2}{*}{2011} & \multirow[b]{2}{*}{ R21/375 } & \multirow[b]{2}{*}{ Pinus massoniana } & B744 & \multirow{2}{*}{$5 / 5$} & \multirow{2}{*}{$3 / 5$} & 28 May \\
\hline & & & & B746 & & & 29 May \\
\hline 12 & 2011 & R30/W01 & Pinus massoniana & B747 & $2 / 2$ & $2 / 2$ & 9 June \\
\hline 13 & 2011 & 359/R27 & Pinus massoniana & B750 & $4 / 4$ & $2 / 4$ & 10 June \\
\hline 14 & 2011 & 221/C63 & Pinus massoniana & B751 & $2 / 2$ & $2 / 2$ & 17 June \\
\hline 15 & 2011 & 177/E47 & Pinus massoniana & B753 & $3 / 3$ & $1 / 3$ & 25 June \\
\hline \multirow{2}{*}{16} & \multirow{2}{*}{2012} & \multirow{2}{*}{ B722/375 } & Pinus massoniana & B07 & \multirow{2}{*}{$4 / 4$} & \multirow{2}{*}{$3 / 4$} & 2 June \\
\hline & & & Pinus massoniana & B08 & & & 4 June \\
\hline 17 & 2012 & W07/W01 & Pinus massoniana & B10 & $3 / 3$ & $2 / 3$ & 30 May \\
\hline 18 & 2012 & 359/R27 & Pinus massoniana & B21 & $4 / 4$ & $2 / 4$ & 10 June \\
\hline \multirow{2}{*}{19} & \multirow{2}{*}{2012} & \multirow{2}{*}{ B737/R20 } & Pinus massoniana & B22 & $3 / 3$ & $3 / 3$ & 20 June \\
\hline & & & Pinus massoniana & B25 & כונד & כיונד & 21 June \\
\hline
\end{tabular}


the period of bird visits and surveys, all 25 individuals completed the entire process of post-fledging dispersal.

\section{Banding and radio-telemetry}

The Crested Ibis feeds and roosts largely near human settlements ( $\mathrm{Li}$ et al. 2002) and their frequent, hoarse calls, especially those given by males early in the breeding season facilitated our efforts to find all nests and mark all nestlings. Twenty-five nestlings from nineteen nests were banded with numbered and colored bands before they fledged at 24-26 days. Each year the bands were checked and verified at nest sites, foraging grounds and winter-roost sites. A radio transmitter set (RI-2D) between 216.368 and $216.691 \mathrm{MHz}$ was placed on the strongest nestlings (typically the eldest) at each nest 23-25 days after hatching. It was attached on the neck using a harness of elastic nylon string, leaving room for growth of the pectoral muscles. At $15 \mathrm{~g}$, its weight was approximately $1 \%$ of the body mass of the fledglings. Battery life was estimated at 18 months. Monitoring was accomplished using programmable receivers (TRX-1000S, Wildlife Materials Inc., Carbondale, IL, USA) and threeelement, hand-held antennas. Radio-marked individuals generally dispersed with family groups or other wandering flocks for three months. During the study, we observed the different groups at dark (17:40-18:40) when all members of a wandering flock perched in a night-roosting sites and the individuals observed in a fledgling group between 7:00 and 12:00 hours on a rotational basis at 1-3 day intervals until contact was lost. However, radio-telemetry was only an auxiliary method; all access to juvenile dispersal data has been collected on the spot as a means of radio-telemetry.

\section{Bird visits and surveys}

We recorded monthly observations of habitat use by hatch-year birds, starting with fledging and ending seven months after fledging. Status (location, survival condition) and behavior were recorded within natal territories five days per week by approaching on foot until the fledgling was sighted or a change in signal strength was recorded. When a signal from a fledgling was lost, we searched across the entire study area and up to $20-40 \mathrm{~km}$ outside of the study area boundary using the radio receiver, a spotting scope (GEOMA65A 20-60x) and binoculars (SICONG $10 \times 42$ ). On each tracking day, at least one location per individual was recorded during each of three periods: early morning (06:00-09:00), mid-day (09:01-15:00) and late afternoon (15:01-20:00). We chose these periods in order to capture movements of the radiomarked fledglings between night roosting sites and daytime foraging and resting areas. The distribution points of dispersal of the radio-marked fledglings were obtained by radio receiver and spotting scope, their geographical positions and dispersal directions $\left(1-360^{\circ}\right.$, the azimuth angle of the newborn individuals between the location and the natal site) were pinpointed using global positioning system (GPS) receivers. The dispersal distance, referring to the straight line distance between the natal site and post-fledging area, was calculated on 1:50000 topographic maps.

The magnitude of pre-dispersal movements by newly fledged Crested Ibises varies significantly among individuals. Therefore we defined the onset of post-dispersal as the date upon which a fledgling stopped using the nest tree as a night roost and termination as the date upon which an individual no longer exhibited a linear, directional movement away from the natal home range, but instead concentrated its daily movements around a night-roosting site we referred to as post-dispersal ranges (or first wintering sites).

\section{Statistical analyses}

All post-dispersal direction analyses were conducted using Oriana 4.01 (Kovach Computing Services, Wales, UK). We calculated the mean vector $(\mu)$ and the angular deviation $(r)$ for the dispersal direction and used Rayleigh's $z$ to test for the directional pattern (Zar 1996). All statistical analyses were conducted using SPSS 16.0 (SPSS Inc., Chicago, USA), presented as mean \pm standard deviation (SD) with significance set at $p=0.05$. Most data were measured by repeated ANOVA. We computed means for observations in the use of forging and roosting habitats for each month of post-fledging, by first averaging the data from observations of all radio-marked members of a sibling group. Pearson correlation analysis was used to compute correlation between mean distances from natal site to foraging ground that breeding pairs frequently attended during the nestling period and days that natal home ranges were occupied.

\section{Results}

\section{Post-fledging dispersal}

All 25 marked fledglings survived to disperse from their natal home ranges to the first wintering grounds. From the time of fledging (the time from hatching to fledging at 39-43 days of age) to dispersal, the number of days $(14.3 \pm 7.0, n=25)$ between fledging and departure from the nest tree (roosting site), varied significantly among individuals and was used to determine the onset of dispersal. Movements of family groups prior to dispersal were centered on nesting sites during the entire period. Ibis fledglings made short excursions into areas surrounding their nest site during the two to three week post-fledging period, generally referred to as natal home ranges. They frequently changed roosting sites near the nest tree following their parents and gave a distinctive begging call with the bill stretched forwards when adult 
birds approached. Crested Ibis fledglings typically flew less than $100 \mathrm{~m}$ and perched in forest patches at the edge of habitats, because fledglings at this stage are relatively inactive and incapable of long sustained flight. Afterwards, fledglings began to learn to forage but were partially dependent upon parental care. Typically, feeding did not exceed 2-3 bouts each day. After restricted pre-dispersal movements around the natal nest, juvenile dispersal begins at the second month of life. Siblings increasingly became independent of their parents by midAugust and then moved progressively farther from their natal home ranges to post-dispersal ranges, with a mean direction $\left(\mu=254.6^{\circ}, \check{s}=70.5^{\circ}, r=0.469\right.$, Rayleigh's $z$ : $p=0.003 ; n=25$, Figure 1$)$ and a mean distance of $5.1 \pm 5.8 \mathrm{~km}(n=25$; Figure 2$)$. It took $56.4 \pm 38.6$ days (range 1-118 days) for juveniles to disperse from their natal home ranges to their post-dispersal ranges $(n=25)$.

\section{Habitat use}

We identified post-dispersal habitat types for 11 of our 25 surviving juveniles (two juveniles from two broods in 2008, four juveniles from two broods in 2009 and five juveniles from four broods in 2010). The juveniles used a wide range of different habitat types for foraging and roosting.

Feeding habitat types included paddy fields, shallow rivers, arid croplands, grasslands and streams. Use of post-dispersal feeding habitats varied from month to

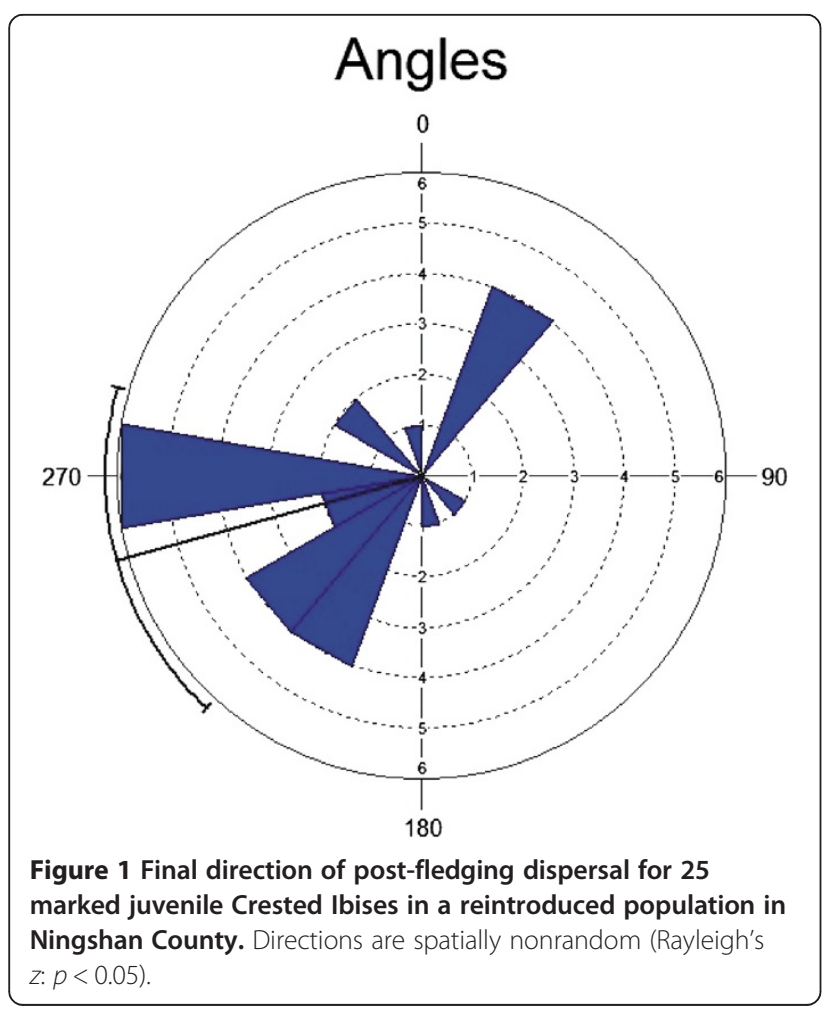

month. In the early period of post-dispersal the Crested Ibis individuals forged, mainly as a small group, in a dispersed manner, although the juveniles often moved together with their parents forming family groups. As shown in Table 2, shallow rivers and paddy fields became the primary and substitute habitat types during the entire period of post-fledging dispersal.

Roosting habitat types included coniferous-broadleaf forests (Masson pine and other tree species, such as Castanea mollissima, Gleditsia sinensis, Sophora japonica, Acer elegantulum, Populus davidiana and Juglans regia) and other perches, such as rock outcrops, poles and the edges of fields. In our study, nearly all nest-tree species $(85.7 \%)$ were located in mature forests dominated by Masson pine (Table 1). Although the use of Masson pines decreased linearly over time (two-way ANOVA: $F_{20}, 126=3.17, p=0.000$, Table 3 ) from June $($ Mean $\%=65.2, \mathrm{SD}=4.3)$ to December $($ Mean $\%=30.0$, $\mathrm{SD}=0.5$ ), this habitat type was by far the most abundant and available to juveniles before the onset of dispersal. Stands of pine forest are interspersed with mature oak forests close to paddy fields near local farm settlements. Trunk sizes range from 32 to $49 \mathrm{~cm}$ in DBH and canopy heights from 6.5 to $15.3 \mathrm{~m}$. During the post-dispersal period, use of other tree species increased gradually from June to September and remained stable from September to December. We found that fledglings also used rock outcrops, poles and the edges of fields as temporary resting areas between periods of foraging (Table 3). Fledglings formed wandering flocks composed of many adults and juveniles from different family groups. These groups used transient roosting sites until they arrived at their overwintering sites. Of the 11 tracked fledglings, five individuals $(45.5 \%)$ used three roosting sites, four individuals (36.4\%) used four roosting sites and of two (18.1\%) individuals one used two roosting sites and the last bird only one.

\section{Discussion}

The Crested Ibis was widespread and locally abundant in Northeast Asia in the late $19^{\text {th }}$ century, when it nested in the Russian Far East, Japan and mainland China. It was also presumed to be a winter visitor to the Korean Peninsula (BirdLife International 2001). The surviving wild population in Yangxian County and the reintroduced population in Ningshan County are residents that make only relatively short, seasonal movements between nesting and wintering sites (Shi and Cao 2001; Yu et al. 2010). However, in the past, the former population of Siberia (eastern Russia), northeast China, and Hokkaido (northern Japan) are known to have migrated south in winter (Yamshina 1967; Archibald et al. 1980; Yusuda 1988). The Crested Ibis perhaps exhibits different patterns of post-fledging movements in their former and 


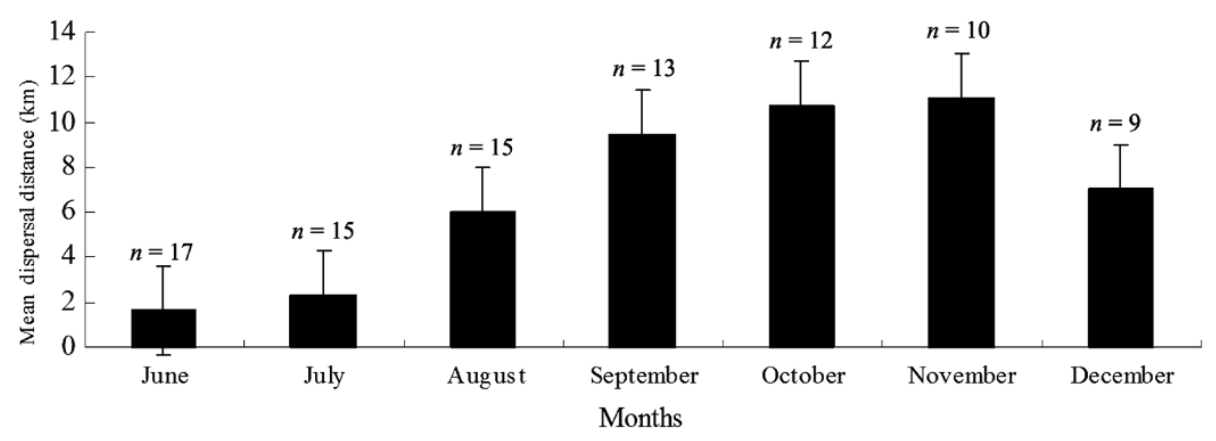

Figure 2 Mean $( \pm S D)$ post-fledging distances of the Crested lbis (June-December) in a reintroduced population in Ningshan County.

present ranges. We have no way of measuring the exact distance they travel to their wintering grounds at the Korean Peninsula, Taiwan or Hainan Island from the former breeding sites in Russia and northeastern China, but estimates suggest that this distance exceeds hundreds of kilometers.

In our study, the dispersal distances of the 25 individuals that completed the entire process of post-fledging dispersal were less than $16 \mathrm{~km}$, suggesting that the postfledging dispersal distance in the first year was highly correlated with the distance between suitable breeding and wintering habitat areas. In comparison, the natal home ranges of fledglings of the reintroduced population were occupied for significantly shorter periods than that of the wild population (21.1 \pm 10.2 days, $n=36 ; t=3.047$, $p=0.004)$. Most fledglings moving southwest were concentrated at the mean direction $\left(\mu=254.6^{\circ}, \check{s}=70.5^{\circ}, n=\right.$ $25)$ while fledglings of wild birds dispersed in a southerly direction $\left(189.2 \pm 46.5^{\circ}, n=36\right)$ with a mean dispersal distance of $20.3 \pm 7.0 \mathrm{~km}(n=36)$ (Yu et al. 2010). The overall pattern of post-fledging dispersal of juveniles is similar for the wild and reintroduced populations, but the fledglings of the wild population dispersed four times as far as the reintroduced individuals. These findings are very useful for us to predict the distance and direction of dispersal under various landscape conditions of other released sites.

The process of avian dispersal begins when an individual fledges from its nest and is then guided by a series of decisions: where to move, what to eat, with whom to pair and ultimately where to attempt breeding. Post-fledging dispersal is one of the most important stages in the lifehistory of birds. Only upon finding a mate and attempting to breed can the dispersal process be regarded as complete. In our study area, juvenile ibis birds moved an average of $5.1 \mathrm{~km}$ away from their natal territory during the first year of their life. It took a minimum of two years for fledglings to become sexually mature. Sexual monomorphism in Crested Ibis fledglings makes gender assignment difficult to distinguish during the postfledging dispersal period. Our observations of the dispersal of ibis fledglings indicate that they are not moving randomly. Similar to wild fledglings (Yu et al. 2010) and resident Golden Eagles (Aquila chrysaetos; Soutullo et al. 2006), the juvenile dispersal of our population reared in captivity is typically characterized by an initial exploratory and nomadic phase followed by repeated returns to the vicinity of the natal area. Siblings of each brood increasingly became independent of their parents at the beginning of August and all fledglings routinely joined ibis

Table 2 Per cent use of post-fledging dispersal feeding habitats by juvenile Crested Ibises

\begin{tabular}{|c|c|c|c|c|c|c|c|c|}
\hline \multirow[b]{2}{*}{ Habitat } & \multicolumn{7}{|c|}{ Post-fledging month } & \multirow[b]{2}{*}{$p^{b}$} \\
\hline & $\begin{array}{l}\text { June } \\
\text { (Obs =54) } \\
\text { Mean\% (SD) } \\
\left(n^{\mathrm{a}=7)}\right.\end{array}$ & $\begin{array}{l}\text { July } \\
\text { (Obs = 15) } \\
\text { Mean\% (SD) } \\
(n=12)\end{array}$ & $\begin{array}{l}\text { August } \\
\text { (Obs }=14) \\
\text { Mean\% (SD) } \\
(n=12)\end{array}$ & $\begin{array}{l}\text { September } \\
(\text { Obs }=12) \\
\text { Mean\% (SD) } \\
(n=10)\end{array}$ & $\begin{array}{l}\text { October } \\
\text { (Obs =32) } \\
\text { Mean\% (SD) } \\
(n=10)\end{array}$ & $\begin{array}{l}\text { November } \\
(\text { Obs }=50) \\
\text { Mean\% (SD) } \\
(n=10)\end{array}$ & $\begin{array}{l}\text { December } \\
\text { (Obs =12) } \\
\text { Mean\% (SD) } \\
(n=8)\end{array}$ & \\
\hline Paddy fields & $55.2(4.3)$ & $35.7(3.7)$ & $30.8(3.1)$ & $30.0(3.2)$ & $54.0(2.0)$ & $71.4(6.7)$ & $100(1.5)$ & 0.015 \\
\hline Shallow rivers ${ }^{c}$ & 0.0 & $41.3(19.1)$ & $62.4(26.8)$ & $66.7(22.9)$ & $42.1(2.3)$ & 28.6(1.9) & 0.0 & 0.003 \\
\hline Arid croplands & 29.4(3.2) & $5.7(0.9)$ & $1.1(0.4)$ & $1.6(0.4)$ & 0.0 & 0.0 & 0.0 & 0.891 \\
\hline Grasslands & 0.0 & $15.8(2.3)$ & $1.6(0.5)$ & $1.7(0.7)$ & $3.9(0.4)$ & 0.0 & 0.0 & 0.873 \\
\hline Streams $^{c}$ & $15.4(3.5)$ & $1.5(0.5)$ & $4.0(1.2)$ & 0.0 & 0.0 & 0.0 & 0.0 & - \\
\hline
\end{tabular}

${ }^{a}$ Number of sibling groups observed.

${ }^{\mathrm{b}} p$-values are based on ANOVA F-tests for linear trends across seven month post-fledging period.

'Shallow rivers ( $\geq 5 \mathrm{~m}$ in width), streams ( $<5 \mathrm{~m}$ in width). 
Table 3 Per cent use and availability of post-dispersal roosting habitats by juvenile Crested Ibises

\begin{tabular}{|c|c|c|c|c|c|c|c|c|}
\hline \multirow{4}{*}{ Habitat } & \multicolumn{7}{|c|}{ Post-fledging month } & \multirow{4}{*}{$p^{b}$} \\
\hline & $\begin{array}{l}\text { June } \\
\text { (Obs =73) }\end{array}$ & $\begin{array}{l}\text { July } \\
\text { (Obs = 18) }\end{array}$ & $\begin{array}{l}\text { August } \\
(\text { Obs }=10)\end{array}$ & $\begin{array}{l}\text { September } \\
(\text { Obs = 11) }\end{array}$ & $\begin{array}{l}\text { October } \\
(\text { Obs }=77)\end{array}$ & $\begin{array}{l}\text { November } \\
\text { (Obs }=75 \text { ) }\end{array}$ & $\begin{array}{l}\text { December } \\
(\text { Obs =11) }\end{array}$ & \\
\hline & Mean\% (SD) & Mean\% (SD) & Mean\% (SD) & Mean\% (SD) & Mean\% (SD) & Mean\% (SD) & Mean\% (SD) & \\
\hline & $\left(n^{\mathrm{a}}=4\right)$ & $(n=8)$ & $(n=8)$ & $(n=8)$ & $(n=8)$ & $(n=8)$ & $(n=5)$ & \\
\hline Masson pine & $65.2(4.3)$ & $63.6(5.8)$ & $54.1(4.4)$ & $46.1(9.3)$ & $43.3(7.7)$ & $42.6(7.7)$ & $30.0(0.5)$ & 0.000 \\
\hline Other tree species & 18.8(5.3) & 19.3(7.2) & $26.3(5.5)$ & $42.6(4.1)$ & 42.1(4.0) & $47.2(1.7)$ & $45.0(0.5)$ & 0.092 \\
\hline Other perches ${ }^{c}$ & 15.9(4.3) & $17.0(3.8)$ & 19.6(2.1) & $11.3(2.5)$ & $14.6(1.3)$ & $10.2(1.8)$ & $25.0(0.5)$ & - \\
\hline
\end{tabular}

${ }^{a}$ Number of sibling groups observed.

${ }^{\mathrm{b}} p$-values are based on ANOVA F-tests for linear trends across seven months post-fledging period.

'Other perches include rock outcrops, poles and field edges.

flocks that included other non-breeders in post-dispersal areas. Breeding opportunities may be more likely in these dispersal flocks than they would be if these young birds were to remain with the family group. In dispersal flocks, individuals may be capable of competing for new territories, thus becoming active breeders by dominating these new areas (Zack and Stutchbury 1992). The fall/winter flocking period provides an opportunity to interact with possible mates and appears to be very important for sustaining the surviving population. We observed that, within dispersal flocks, adults frequently forced juveniles to roost on peripheral branches through a ritualistic pecking behavior. New pair formation occurs often following the flocking period in late winter and early spring (Shi and Cao 2001).

According to the optimal foraging theory, the distribution and temporal use of habitat varies due to habitat quality (Lester et al. 2007). The period that territories were occupied by the reintroduced population were $14.3 \pm$ 7.0 days $(n=25)$ and $21.1 \pm 10.2$ days $(n=36)$ for the wild population (Yu et al. 2010), which appears to reflect differences in food availability at different nesting sites. The nestlings of the Crested Ibis fledged approximately from midJune to mid-July and were prevented from foraging in rice fields due to the inaccessibility of the flourishing rice shoots. Therefore, fledglings and their parents had to move to feed in alternate habitats such as rivers and grasslands during this period. In the following months, they returned to their main foraging sites (paddy fields; Table 2). From our study, we speculate that the proximate cause for dispersal of the Crested Ibis is increasing food availability during the conversion process of habitat, but potential pairs and pairing formation eventually might be found in colonies during the dispersal process and thus achieve population continuity, which is the ultimate factor for the post-dispersal of the birds (the remote cause).

Since 1999, great success for both the wild and captive populations has led some ornithologists to a more positive view regarding long-term reintroduction goals, restoring the species to its former range (Zheng 2000; Litvinenko 2000). To date, reintroduction programs have been conducted in 2007 in China (Yu et al. 2009) and in 2008 in Japan (Nishimiya and Hayashi). The eggs failed to hatch on Japan's Sado Island, but the worldwide program still achieved one of its first goals as new pair formations continued to occur and the number of fledglings produced continued to grow in our study area, Ningshan County (Yu et al. 2009, Li et al. 2011). Recent investigation of the historical range for this species suggests that regions south of the Qinling mountains should be prioritized for future release efforts. Conservation of migratory endangered species entails preserving adequate breeding, stopover and winter habitats. This may therefore pose greater challenges for managers than resident species do (Serra et al., 2011). Prior to future release in Siberia and the demilitarized zone (DMZ) at the Imjingak Pavilion in Korea, an extensive investigation should be conducted, because the condition of their former breeding ranges, wintering grounds, and stopover sites remains unknown.

In our study, eight recorded mortalities were split evenly between dependent and independent fledglings. Based on the temporal distribution of dead Crested Ibis birds of the reintroduced population in Ningshan ( $\mathrm{Li}$ et al. 2013), the time of death of the juveniles was concentrated in the May-August period, including the period of natal home ranges during post-fledging dispersal. Out of nineteen mortalities incurred among released adults during the 6-year period (three in 2007, three in 2008, four in 2009, three in 2010, two in 2011 and four in 2012), eight of them died from starvation, two were lost due to electrocution by power lines, four died due to predation or injuries attributable to predation (likely due to martens Martes flavigula, a small-size Mustelidae mammal) and one died from unknown causes ( $\mathrm{Li}$ et al. 2013). These findings indicate that starvation, especially in winter, can be a significant cause of mortality. We propose therefore the following suggestions to management.

The local government should promote a strategy to harmonize people and nature with a particular focus on sustainable agricultural practice that encourages local farmers to cultivate more rice fields within Crested Ibis release areas. The ibis, its habitat and the local communities 
will all benefit. Food (mainly loach, Misgurnus anguillicaudatus) should be supplemented to the rice fields where ibis regularly forage, especially during the winter when the temperature is below $0^{\circ} \mathrm{C}$. Public education should be implemented to inform local people on the purpose of ibis conservation and on how to get involved. The effects on ibis populations of illegal hunting for frogs, fishes and commercial activities nearby shallow rivers should be made clear and all relevant resource protection laws should be strictly enforced.

\section{Conclusions}

The project carried out in Ningshan County, Shaanxi Province is a good example for reintroducing endangered species to their historical ranges. Compared with the wild population in Yangxian County, the juveniles produced from the released population exhibited a similar pattern of post-fledging dispersal. Our results are very useful for us to predict the distance and direction of dispersal under various landscape conditions of other released sites. The food availability during the conversion process of different types of habitat may be the proximate cause for dispersal, and potential pair formations which achieve population continuity are probably the ultimate factor for the post-fledging dispersal. These findings will be valuable for the protection of reintroduced populations of this critically and other endangered species.

\section{Competing interests}

The authors declare that they have no competing interests.

\section{Authors' contribution}

HZP, GJF carried out the field observation and drafted the manuscript; LX focused his energy on radio-tracking and field data collection; YXP was the director of the foundation project who mainly responsible for major revision of the reviewed manuscript. All authors read and approved the final version of the manuscript.

\section{Acknowledgements}

We are very grateful to the support and help from the Life Science College of Shaanxi Normal University, and the reintroduction base of Crested Ibis in Ningshan County for providing us the adequate requirements of daily life and related techniques uesd to observation. Special thanks Mr. R.Hammond and R.Hamilton for their careful comments and help in the editing of the manuscript. We also thank Cao Hai-xin for assistance in field observation and Ningshan County meteorological station for providing meteorological information. Financial support was provided by National Nature Science Foundation of China (31172103).

\section{Author details}

${ }^{1}$ College of Life Sciences, Shaanxi Normal University, Xi'an 710062, China. ${ }^{2}$ Reintroduction Center of Crested Ibis of Ningshan, Ningshan County, Ankang 725000, China.

Received: 31 July 2014 Accepted: 9 August 2014 Published online: 03 November 2014

\section{References}

Archibald GW, Lantis SDH, Lantis LR, Munetchika I (1980) Endangered ibises, Threskiornithinae: their future in the wild and in captivity. Int Zoo Yearbook 20:6-17
Baker RR (1993) The function of post-fledging exploration: a pilot study of three species of passerines ringed in Britain. Ornis Scand 24:71-79

Barbraud C, Johnson AR, Bertault G (2003) Phenotypic correlates of post-fledging dispersal in a population of greater flamingos: the importance of body condition. J Anim Ecol 72:246-257

Bent AC (1953) Life histories of North American Wood Warblers. US Natl Mus Bull 203

Bocetti C (1993) Hatching year Kirtland's Warbler captured in unusual habitat. Wilson Bull 105:532-533

Bull EL, Henjum MG, Rohweder RS (1988) Home range and dispersal of Great Gray Owls in northeastern Oregon. J Raptor Res 22:101-106

Clobert J, Danchin E, Dhont AA, Nichols J (2001) Dispersal-Causes, Consequences and Mechanisms of Dispersal at the Individual, Population and Community Level. Oxford University, Oxford

Ferrer M (1993) Juvenile dispersal behaviour and natal philopatry of a long-lived raptor, the Spanish Imperial Eagle (Aquila adalberti). Ibis 135:132-138

Greenwood PJ, Harvey PH (1982) The natal and breeding dispersal of birds. Annu Rev Ecol Syst 13:1-21

Howard WE (1960) Innate and environmental dispersal of individual vertebrates. Am Midland Nat 63:152-161

International BL (2001) Threatened Birds of Asia: The BirdLife International Red Data Book. Cambridge, UK

Lester SE, Ruttenberg BI, Ganines SD, Kinlan BP (2007) The relationship between dispersal ability and geographic range size. Ecol Lett 10:745-758

Li XH, Ma ZJ, Ding CQ, Zhai TQ, Li DM (2002) Relationship between the distribution of Crested Ibis and local farmers. Acta Zool Sinica 48:725-732 (in Chinese)

Li X, Chen WG, Shi L, Dong R, Yu XP (2011) Conservation and research status of the Crested Ibis (Nipponia nippon). In: Studies on Chinese Ornithology, Proceedings of $11^{\text {th }}$ Ornithological Symposium of China Ornithological Society, Lanzhou., pp 176-186

Li X, Huo ZP, Yu XP (2013) Cause of death of the Crested Ibis of a reintroduced population in Ningshan, Shaanxi. Chin J Zool 48:701-706 (in Chinese)

Litvinenko NM (2000) Crested Ibis in Russia: yesterday, now and tomorrow. In: Proceedings of the International Workshop on the Crested Ibis Conservation '99. China Forestry Publishing House, Beijing, pp 223-224

Liu YZ (1981) The re-discovery of the Crested Ibis in Qinling Mountain. Acta Zool $\operatorname{Sin}$ 27:273 (in Chinese)

Liu DP, Qing DC, Chu GZ (2003) Home range and habitat utilization of the crested ibis in the breeding period. Acta Zool Sin 49:755-763 (in Chinese)

Morton ML (1991) Post-fledging dispersal of Green tailed Towhees to subalpine meadow. Condor 93:466-468

Nishimiya H, Hayashi K Reintroducing the Japanese Crested Ibis in Sado, Japan., http://www.teebweb.org

Nolan V (1978) The ecology and behavior of the Prairie Warbler Dendroica discolor. Ornithol Monogr 26

Paradis E, Baillie SR, Sutherland WJ, Gregory RD (1998) Patterns of natal and breeding dispersal in birds. J Anim Ecol 67:518-536

Pulich WM (1976) The Golden-cheeked Warbler: a Bioecological Study. Texas Parks and Wildl. Dept, Austin, TX

Rappole JH, Ballard K (1987) Passerine post-breeding movement in a Georgia old field community. Wilson Bull 99:475-480

Serra G, Bruschini C, Lindsell JA, Peske L, Kanani A (2011) Breeding range of the last eastern colony of critically endangered Northern Bald Ibis Geronticus eremite in the Syrian steppe: a threatened area. Bird Conserv Int 21:284-295

Shi DC, Cao YH (2001) The Crested Ibis in China. China Forestry Publishing House, Beijing (in Chinese)

Soutullo A, Urios V, Ferrer M, Penarrubia SG (2006) Post-fledging behaviour in Golden Eagles Aquila chrysaetos: onset of juvenile dispersal and progressive distancing from the nest. Ibis 148:307-312

Walls S, Kenward RE (1995) Movements of radio-tagged Buzzards (Buteo buteo) in their first year. Ibis 137:177-182

Yamshina Y (1967) The plight of the Japanese Crested Ibis. Animals 10:275-277

Yu XP, Chang XY, Li X, Chen WG, Shi L (2009) Return of the Crested Ibis Nipponia nippon: a reintroduction programme in Shaanxiprovince, China. BirdingASIA 11:80-82

Yu XP, Xi YM, Lu BZ, Li X, Gong MH, Shi L, Dong R (2010) Post-fledging and Natal dispersal of Crested Ibis in the Qinling mountains, China. Wilson J Ornithol 122:228-235

Yusuda K (1988) Literature relating to Japanese Crested Ibis, Nipponia nippon, 9. Bull Appl Ornithol 8:68-82

Zack S, Stutchbury BJ (1992) Delayed breeding in avian social systems: The role of territory quality and 'floater' tactics. Behaviour 123:194-218 
Zar JH (1996) Biostatistical Analysis, 3rd edn. Prentice-Hall, Englewood Cliffs, New Jersey, USA

Zheng GM (2000) The direction of researches on the endangered species of birds in China. In: China Ornithological Society (ed) Proceedings of the International Workshop on the Crested Ibis Conservation '99. China Forestry Publishing House, Beijing, pp 19-23, in Chinese

doi:10.1186/s40657-014-0007-5

Cite this article as: Huo et al:: Post-fledging dispersal and habitat use of a reintroduced population of the Crested lbis (Nipponia nippon). Avian Research 2014 5:7.

\section{Submit your next manuscript to BioMed Central} and take full advantage of:

- Convenient online submission

- Thorough peer review

- No space constraints or color figure charges

- Immediate publication on acceptance

- Inclusion in PubMed, CAS, Scopus and Google Scholar

- Research which is freely available for redistribution 